\title{
Course of Aggressive Somatotroph, Corticotroph and Mammotroph Tumors under Temozolomide: Report of Three Cases and Review of the Literature
}

\author{
Berna Imge AYDOGAN, Ugur UNLUTURK, Rifat EMRAL, Sevim GULLU \\ Ankara University, Faculty of Medicine, Department of Endocrinology and Metabolism, Ankara, Turkey
}

\section{ABSTRACT}

\begin{abstract}
Treatment of aggressive pituitary tumors may be challenging. Temozolomide (TMZ) is a promising agent when conventional treatment methods fail. We present three patients with aggressive pituitary tumors with atypical morphology, who were resistant to conventional treatments and treated with TMZ. The first case had a somatotroph adenoma, the second a corticotroph adenoma, and the third a macroprolactinoma. We also reviewed the literature reporting TMZ efficacy in somatotroph, corticotroph and mammotroph tumors of the pituitary gland. TMZ with a schedule of $150-200 \mathrm{mg} / \mathrm{m}^{2}$ for 5 days every 28 days was administered to all patients. Even though only the case of macroprolactinoma had a favorable response to TMZ treatment among our patients, both radiological and hormonal recurrence occurred 30 months after the cessation of TMZ treatment. TMZ treatment was then administered again. Cases of somatotroph and corticotroph adenomas had progressed under TMZ treatment and the patients were lost due to mass effect of the tumor. A review of the literature demonstrated $67.3 \%, 60 \%$ and $26.7 \%$ overall response rates to $\mathrm{TMZ}$ treatment in prolactinoma, corticotropinoma and somatostatinoma cases, respectively. There is still a need to define response criteria uniformly to TMZ treatment in aggressive pituitary tumors. The duration of response should be reported for reliable evaluation of results.
\end{abstract}

KEYWORDS: Aggressive pituitary adenoma, Cushing's disease, Macroprolactinoma, Somatotroph adenoma, Temozolomide

ABBREVIATIONS: MGMT: O6Methylguanine DNA methyl-transferase, TMZ: Temozolomide, APA: Atypical pituitary adenoma, PC: Pituitary carcinoma, MSH6: DNA mismatch repair protein, PRL: Prolactin

\section{INTRODUCTION}

$\mathrm{P}$ ituitary adenomas (PAs) are relatively frequent tumors with an estimated prevalence of 80-90 per 100,000 and account for $15 \%$ of intracranial neoplasms $(25,55)$. The large majority of pituitary adenomas are benign. However, aggressive, invasive or malignant tumors of the pituitary gland may develop and treatment of these tumors is quite challenging. A classification for pituitary adenomas was developed by World Health Organization (WHO) in 2004 (39). The WHO classification suggested the prediction of potentially "aggressive adenomas" with histopathological features.
Atypical pituitary adenoma (APA) and pituitary carcinoma (PC) were defined according to immunohistochemical staining characteristics and presence of metastasis. Adenomas with atypical morphological features of invasive growth, increased number of mitoses, extensive nuclear staining for p53, and a Ki67 (MIB-1) proliferation index of 3\% or more were classified as APAs. In surgical series, APAs were identified in 2.7-14.8\% of resected pituitary adenomas $(63,76)$. "Aggressive pituitary adenoma" is a clinical description of tumors characterized by invasion to adjacent tissues, early recurrence and resistance to classical first line treatments. Clinical behavior of aggressive 
adenomas is different from both benign and malign adenomas and they can be considered as an intermediate form. APAs may not be aggressive tumors and also aggressive adenomas may not be APAs. However, atypical histopathology according to WHO criteria was suggested as an independent risk factor for aggressive tumor behavior (1).

PCs and aggressive/atypical adenomas are usually resistant to conventional treatments and have poor prognosis $(33,68,76)$. Conventional chemotherapeutic drugs do not have impact on survival and tumor recurrence in these tumors $(33,68)$. Thus, PCs /APAs require additional treatment modalities when residual or recurrent tumors are resistant to classical treatment options.

Temozolomide (TMZ) is an orally administered, secondgeneration, alkylating chemotherapeutic drug capable of crossing the blood-brain barrier (5). The principal mechanism responsible for the cytotoxicity of TMZ is the methylation of deoxyribonucleic acid (DNA) that results in strand breaks and cell death (42). TMZ was shown to be a promising chemotherapeutic drug for salvage therapy of aggressive adenomas and PCs. In the last decade, TMZ treatment has been used in aggressive pituitary adenomas and carcinomas that were resistant to classical treatment options. Since the first case of aggressive pituitary adenoma was treated with TMZ, more than 100 cases of pituitary tumors including PCs and aggressive adenomas managed with TMZ have been reported $(16,79)$. Even though these case reports and small series have shown that TMZ could be an alternative treatment option for PCs and aggressive adenomas, there is still a need for more experience in using this drug due to the heterogeneous and limited number of results among same pituitary tumor types. Experience with somatotropinomas is especially limited with only fourteen cases and not sufficient to create a general impression $(6,7,12,27,43,50,72)$.

We therefore present our experience with TMZ in the management of three aggressive pituitary adenomas, somatotroph, corticotroph and mammotroph tumors, refractory to conventional treatment strategies. In addition, we reviewed the literature reporting TMZ efficacy in these tumors.

\section{CASE REPORTS}

\section{Case 1}

The first patient was a 55-year-old man who had an invasive growth hormone $(\mathrm{GH})$-secreting pituitary macroadenoma. He presented in September 2006 with headache, visual loss, perspiration, enlarged hands and feet. Physical examination demonstrated macroglossia, enlargement of hands and feet, prognathism, frontal bossing, mandibular enlargement and teeth separation. His pulse rate was 78 beats per minute and blood pressure was 150/90 mm $\mathrm{Hg}$. On laboratory examination, the serum IGF-1 level was $691 \mathrm{ng} / \mathrm{ml}$ (normal range [N]; 94-284) and $\mathrm{GH}$ level was $2.7 \mathrm{mcg} / \mathrm{L}(\mathrm{N}, 0-6.7$ $\mathrm{mcg} / \mathrm{L})$. The GH level was not suppressed $(>1.9 \mathrm{mcg} / \mathrm{L})$ after a 75 -gram oral glucose load. Pituitary magnetic resonance imaging (MRI) revealed a giant macroadenoma with suprasellar extension and invasion of the right sphenoid sinus.
He underwent transnasal/transsphenoidal (TN/TS) pituitary adenomectomy. The resected tissue was a $\mathrm{GH}$-secreting adenoma with $10 \% \mathrm{Ki} 67$ proliferation index and extensive p53 staining. O-6-methylguanine-DNA methyltransferase (MGMT) immunostaining was not available.

In October 2008, laboratory examination showed an elevated insulin-like growth factor-1 (IGF-1) level $(352 \mathrm{ng} / \mathrm{ml})$. Pituitary MRI demonstrated a $20 \mathrm{~mm}$ recurrent adenoma. Octreotide LAR treatment at a dose of $20 \mathrm{mg}$ per month was initiated. He underwent right pterional craniotomy in April 2009 and stereotactic radiosurgery in July 2009 (14 Gy)(Gamma Knife, Elekta Instruments, and Stockholm, Sweden). Although octreotide LAR was continued at a dose of $30 \mathrm{mg} / \mathrm{month}$, neither hormonal nor tumoral response was achieved. Temozolomide treatment was started at a dose of $200 \mathrm{mg} /$ $\mathrm{m}^{2} /$ day, for 5 days every 28 days. During the first six cycles, tumor growth was stabilized but progression occurred despite the continuation of treatment at the $12^{\text {th }}$ month of treatment (Figure 1A, B). He died because of local tumor effects.

\section{Case 2}

A 29-year-old man presented with loss of libido and malaise. On physical examination, his blood pressure was $130 / 90 \mathrm{~mm}$ $\mathrm{Hg}$ and pulse rate was 84 beats per minute. He had abdominal purple blue wide striae, proximal muscle weakness and facial plethora. Laboratory investigations showed elevated urinary free cortisol level of $138 \mathrm{mcg} / 24 \mathrm{hrs}$ (normal range [N]; 10$80 \mathrm{mcg} / 24 \mathrm{hrs}$ ). Cortisol suppression was not obtained after overnight $1 \mathrm{mg}$ and subsequent $2 \mathrm{mg}$ (classical two days) dexamethasone suppression tests $(30.2 \mathrm{mcg} / \mathrm{dl}$ and 26.6 $\mathrm{mcg} / \mathrm{dl}$ respectively). Plasma adrenocorticotropic hormone (ACTH) level was normal (32 pg/ml, N;7.2-63.3 pg/ml). Pituitary MRI revealed a macroadenoma $24 \mathrm{~mm}$ in diameter, invading the left cavernous sinus and internal carotid artery (ICA) (Figure 2A-C). The visual field was normal. Adrenal computed tomography (CT) showed normal adrenal glands. These findings indicated ACTH-dependent Cushing's disease. The patient underwent TN/TS pituitary adenomectomy. Histopathological examination showed a 99\% ACTH-positive adenoma with $10 \%$ Ki67 proliferation index and extensive p53 staining.

Postsurgical pituitary MRI revealed a residual mass adjacent to the left ICA. Stereotactic radiosurgery (25Gy) (CyberKnife, Accuray, Sunnyvale, California, USA) was used for the patient due to the presence of a residual tumor on pituitary MRI and left eyelid ptosis. After this treatment, the ptosis regressed dramatically. Four months later, Pasireotide $(600 \mu \mathrm{g}$, subcutaneously, twice daily) treatment was started. The only side effect of pasireotide was mild hyperglycemia that responded to oral antidiabetic treatment. At the second month of pasireotide therapy, right eyelid ptosis occurred. Pituitary MRI showed that the residual mass on the left side had totally disappeared but there was a new macroadenoma located on the right side of the adenohypophysis (Figure 2A-C). Radiotherapy was not planned again because of the short time period after the first session of Cyber Knife and possible side effects on the optic chiasm. The patient underwent a second TN/TS adenomectomy. Immunohistochemistry revealed extensive 

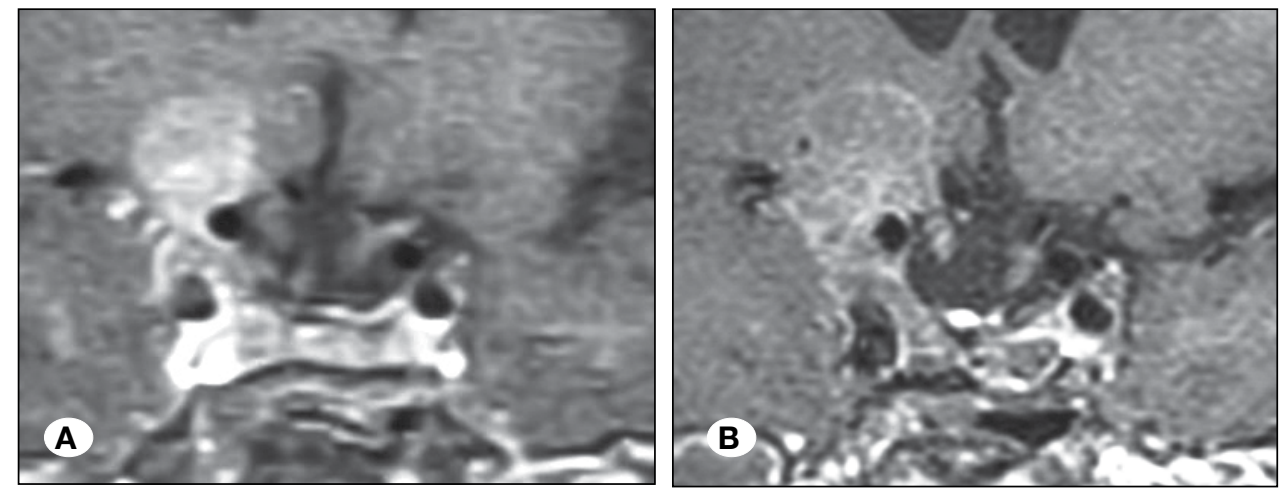

Figure 1: A) Pretreatment T1 coronal-weighted magnetic resonance images showing a sellar mass $37 \mathrm{~mm}$ in its maximum diameter, expanding the sella with a suprasellar component which elevated the right side of optic chiasm, invading the right cavernous sinus and right internal carotid artery. B) $12^{\text {th }}$ month of Temozolomide treatment; $\mathrm{T} 1$ coronal MRI demonstrating progression in suprasellar component of tumor.
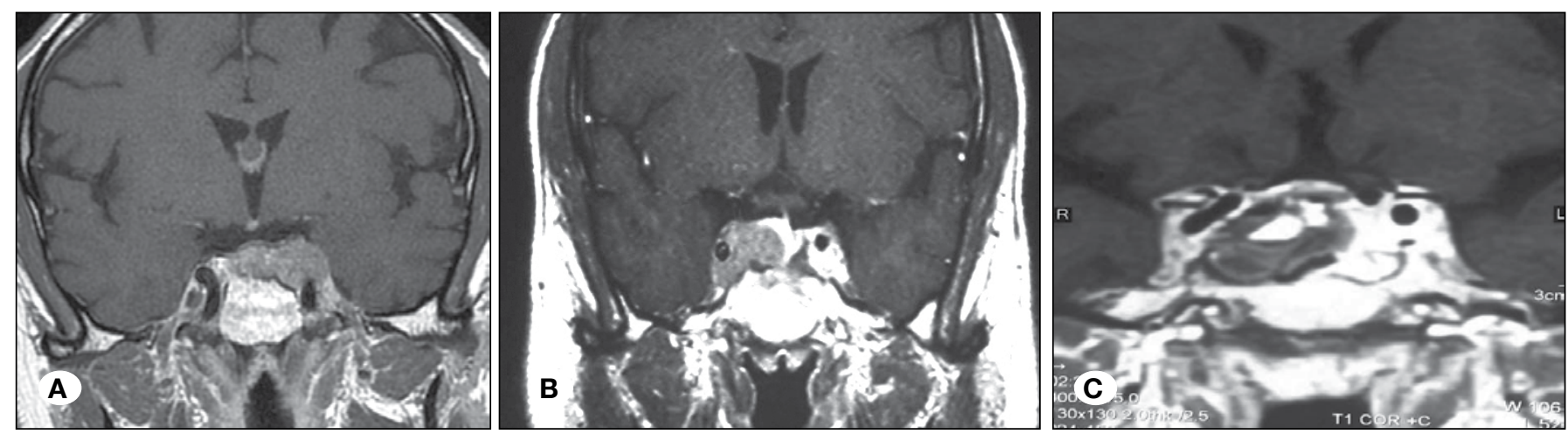

Figure 2: A) At the time of diagnosis; T1-weighted MRI revealed a macroadenoma $24 \mathrm{~mm}$ in diameter, invading the left cavernous sinus and internal carotid artery (ICA). B) Six months after the first session of Cyber Knife; T1-weighted MRI revealed a new adenoma located at the right side of the pituitary invading the right cavernous sinus. C) After second TN/TS adenomectomy; T1-weighted MRI revealed a large cavitation area after total resection of adenoma, showing no residual tumor.

p53 staining (>50\%) and 15\% Ki67 proliferation index. MGMT staining was not available.

Although no mass was observed on pituitary MRI (Figure 2AC), the postoperative clinical picture of patent were consistent with residual disease and the level of urinary free cortisol was $968 \mathrm{nmol} /$ day ( $\mathrm{N}$; 38-208). Temozolomide treatment was started at a dose of $200 \mathrm{mg} / \mathrm{m}^{2} /$ day, for 5 days every 28 days. After three cycles of TMZ, response evaluation showed progressive disease. Urinary free cortisol level was $8658 \mathrm{nmol} /$ day $(\mathrm{N}$; 38-208) and ACTH level was elevated to $197 \mathrm{pg} / \mathrm{ml}(\mathrm{N}$; 7.2-63.3). Pituitary MRI revealed a recurrent mass at the left side of the pituitary. TMZ was no longer continued because of unresponsiveness. The only side effect of TMZ was mild nausea. Left eyelid ptosis relapsed and CyberKnife treatment was applied again. The ptosis regressed after radiosurgery, but hormonal and radiological evidence of disease persisted. The patient was lost due to massive pulmonary thromboembolism.

\section{Case 3}

A 65-year-old woman presented with headache and a previous history of macroprolactinoma in November 2011. On physical examination, her blood pressure was 120/75 mm $\mathrm{Hg}$ and the pulse rate was 70 beats per minute. She had right eyelid ptosis and visual disturbances. Computerized visual field test revealed bitemporal superior quadranopia.
In her medical history; she had been treated with TN/TS pituitary adenomectomy in 1982. Because of tumor progression under bromocriptine treatment, she underwent right frontotemporal/orbitozygomatic craniotomy in 2005. Histology demonstrated a $90 \%$ prolactin (PRL)-positive tumor with $10 \%$ Ki67 proliferation index. One year later, pituitary MRI revealed a $38 \mathrm{~mm}$ adenoma invading the right cavernous sinus and compressing the optic chiasm. Right frontotemporal craniotomy and subtotal tumor excision was performed. In 2010, she was treated with stereotactic radiosurgery (14 Gy, Gamma Knife, Elekta Instruments, Stockholm, Sweden) because of tumor recurrence under bromocriptine treatment.

Radiological and biochemical progression was demonstrated under high dose (7 mg/week) cabergoline therapy in February 2012. Pituitary MRI revealed a $16 \mathrm{~mm}$ adenoma adjacent to right cavernous sinus (Figure $3 \mathrm{~A}-\mathrm{C}$ ). Her prolactin level was $1012 \mathrm{ng} / \mathrm{ml}(\mathrm{N} ; 2.7-19.6)$. TMZ treatment was started at $200 \mathrm{mg} / \mathrm{m}^{2} /$ day for 5 days every 28 days. After six cycles of $\mathrm{TMZ}, \mathrm{PRL}$ level decreased to $60 \mathrm{ng} / \mathrm{ml}$ and continued to fall after the cessation of therapy. Pituitary MRI revealed significant cystic degeneration of tumor with no decrease in tumor size (Figure $3 \mathrm{~A}-\mathrm{C}$ ). Cabergoline was restarted at 1 $\mathrm{mg} /$ week dose. PRL level decreased to normal range two months after discontinuation of TMZ. Thirty-six months after cessation of TMZ, rapid elevation in PRL level $(2877 \mathrm{ng} / \mathrm{ml})$ and progression of tumor with increased solid component on 

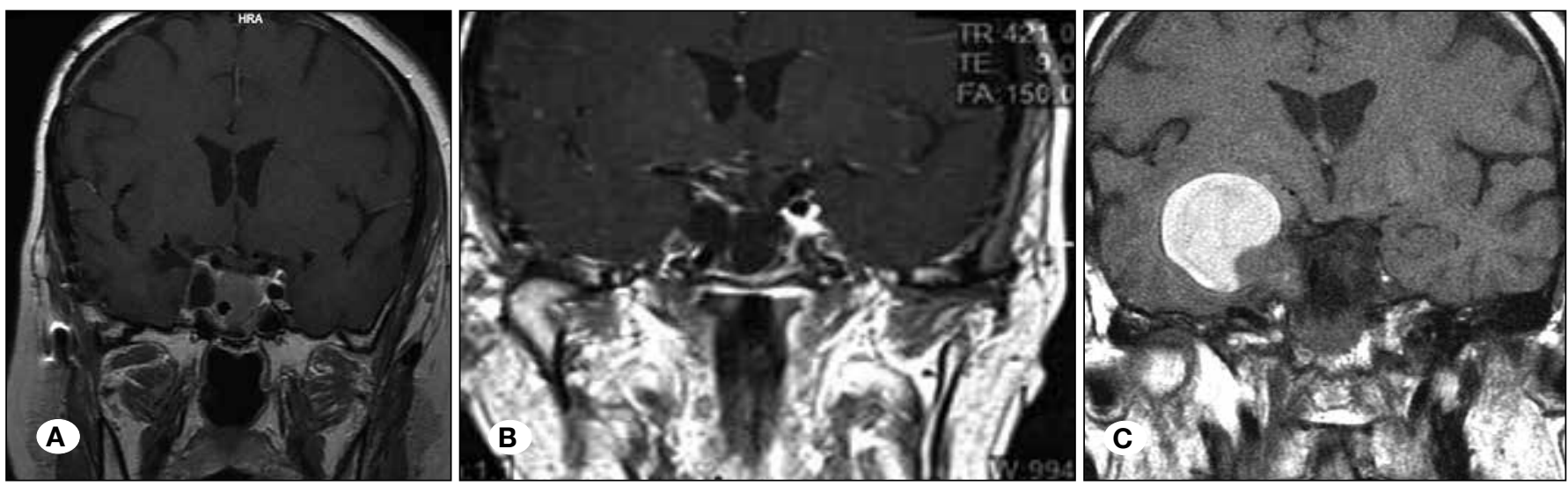

Figure 3: A) Pre-treatment MRI; T1-weighted MRI of the sellar and parasellar regions revealed a 17 mm macroadenoma invading the right cavernous sinus and compressing the optic chiasm. B) After three cycles of TMZ; T1-weighted MRI revealed cystic and hemorrhagic changes in adenoma and reduction of solid component of tumor. C) After TMZ retreatment MRI; T1-weighted MRI revealed a $32 \mathrm{~mm}$ tumor at the right temporal lobe extending from the sella.

MRI were observed. The cabergoline dose was increased to $7 \mathrm{mg} /$ week but no response was seen. TMZ was restarted at $200 \mathrm{mg} / \mathrm{m}^{2} /$ day, for 5 days every 28 days. After three cycles of $\mathrm{TMZ}$, response evaluation revealed tumor progression on pituitary MRI and increased PRL level (3700 ng/ml) (Figure 3AC). Surgery was recommended but the patient did not accept any medical or surgical treatment.

\section{DISCUSSION}

Several cases with aggressive pituitary adenoma or carcinoma treated with $T M Z$ have been published during the last decade with an estimated $60-70 \%$ response rate $(13,60)$. Favorable results were usually reported in macroprolactinomas and adrenocorticotropinomas $(12,13,30,60,73)$. Low expression of MGMT, which is a DNA repair protein and reverses methylation caused by $T M Z$, was suggested as a predictor of good response to $T M Z$ (35).

Management of macrosomatotropinoma may be more challenging, because $40-60 \%$ of them cannot be controlled with surgery, and recurrence of tumor initially thought to be cured by surgery was reported in approximately $10 \%$ of cases $(8,44)$. However, tumor growth after radiotherapy is seen in less than $1 \%$ of patients (8). Experience with TMZ in somatotroph adenomas is limited due to low frequency of resistance to standard treatments or reporting bias. We found fourteen somatotroph tumors treated with $\mathrm{TMZ}$ in the literature (Table I) $(6,7,12,27,43,50,72)$. Bengtsson et al. reported two complete and two partial responses to $\mathrm{TMZ}$ among six somatotroph tumors (outcome data was available for five patients) including three aggressive adenomas and three PCs (7). Partial response was seen in two aggressive tumors (one had a shift from $\mathrm{PRL}$ to $\mathrm{GH}$ secretion) and complete response with normal IGF-1 levels in two carcinomas (one had a shift from $\mathrm{PRL}$ to $\mathrm{GH}$ secretion). Efficacy of $\mathrm{TMZ}$ was also reported in PCs with no relapse at 48 and 91 months of therapy. One of those aggressive adenomas and both of PCs had low (9\%) MGMT immunoexpression. The remaining adenoma with partial response had heterogeneous MGMT immunoexpres- sion $(9-100 \%)$ and tumor recurrence occurred at $15^{\text {th }}$ month of $\mathrm{TMZ}$ treatment. A somatotroph PC with high MGMT expression (90\%) was reported to progress under TMZ treatment. These data may reflect the impact of lower MGMT expression as a good prognostic marker for TMZ response in aggressive macrosomatostatinomas. All other reports of somatotroph adenomas revealed unresponsiveness to TMZ therapy $(6,12,27,40,43,50,72)$. Previously, low MGMT immunoexpression was demonstrated in a majority of somatotroph tumors (83.3\%), including tumors with high Ki-67 labeling index (80). However, two of the reported MGMT negative somatotroph adenomas were non-responders, raising the concerns about significance of MGMT status $(7,12,27)$.

In our case with aggressive somatotroph adenoma, tumor size and IGF-1 level were stable until the sixth cycle of TMZ therapy, but rapid progression occurred thereafter. Consequently, according to the current review of the literature including the present case, the response rate to $T M Z$ among aggressive somatotroph adenomas was $26.7 \%$ (4/15 of cases).

Corticotroph adenomas are more aggressive tumors compared to other pituitary neoplasms $(23,26)$. The five-year mortality rate has been reported as high as $50 \%$ for untreated patients (59). Remission after surgical therapy is achieved in $65-90 \%$ of ACTH-secreting pituitary microadenomas and as low as $25-30 \%$ of macroadenomas in some series $(9,10,19)$. Relapse rate in ten years is also higher for macroadenomas (\%12-36 vs. \%10-20) (9). When residual or recurrent disease is observed; radiotherapy/radiosurgery, medical treatment (somatostatin receptor analogues) and bilateral adrenalectomy are the treatment options. A subgroup of corticotroph tumors is resistant to all conventional therapies. Approximately $50 \%$ of patients cannot be cured with repeated surgery (64). When the MGMT status of invasive and recurrent corticotroph adenomas was investigated, low immunoexpression was demonstrated in $60 \%$ and $86 \%$ of these tumors, respectively (66). Nelson syndrome and Crooke cell macroadenomas were also reported to have low MGMT expression in most cases $(66,71)$. According to these limited data, TMZ has been 
suggested as a salvage therapy for recurrent or incurable Cushing disease. Approximately $70 \%$ of Cushing's disease patients have been reported to be responsive to TMZ (29). Depending on the previous case reports, the sensitivity and specificity of the MGMT status in predicting TMZ responsiveness of corticotroph tumors was reported to be $80 \%$ and $70 \%$ respectively (2).

Forty-nine cases of corticotroph tumors treated with TMZ have been reported in the literature so far (Table II). Among them, 25 PR and 5 CR were noted (Table II). Consequently, according to the current review of the literature, including the present case, the frequency of complete and partial response to TMZ among aggressive corticotroph tumors was $10 \%$ and $50 \%$, respectively. The duration of response was unavailable or quite limited for most cases. The longest lasting effect of TMZ in a corticotroph tumor was 30 months after stopping therapy (12). Five patients had complete response under TMZ treatment $(16,29,41,71)$. One of them had an MGMT positive tumor and others had negative or low MGMT immunoexpression. Eight partial responders were reported to have low or negative MGMT immunoexpression (Table II). Three patients were reported to be non-responders despite negative to low MGMT staining. Unfortunately, MGMT status was not available in the remaining twelve patients, including the present case (Table II).

Approximately $90 \%$ of prolactinomas are responsive to dopamine agonists (49). Aggressive macroprolactinomas are described as dopamine agonist resistant tumors. In most cases, resistance to dopamine agonists develop due to patient incompliance or estrogen replacement (48). Moreover, malignant transformation of the tumor is also reported (31). In cabergoline resistant tumors, surgery generally fails to normalize PRL. TMZ was shown to have efficacy on aggressive macroprolactinomas and is recommended for the treatment of malignant prolactinoma in the recent clinical practice guideline of the Endocrine Society (45). In the literature, according to our best knowledge, 45 aggressive macroprolactinomas treated with $\mathrm{TMZ}$ have been reported (Table III). Only three patients (6.5\%) achieved complete response and all of them had negative/low MGMT immunoexpression $(7,22,24,29)$. Excitingly, one patient was reported to be in remission at 91 months follow-up (7). Twenty-eight patients (60.8\%) were partial responders. Four patients with negative MGMT immunoexpression were resistant to TMZ $(16,29,40,61)$. The MGMT status was unknown in 15 tumors. Even though a partial response under TMZ treatment was achieved initially in the present case with prolactinoma, recurrence was seen after cessation of treatment and tumor progression was detected with re-treatment. Campderá et al. also reported unresponsiveness to second course of TMZ treatment in two previously responsive patients (15). Recently, Strowd et al. reported a case of recurrent macroprolactinoma re-treated with TMZ (69). They observed rapid $P R L$ reduction and partial response on $\mathrm{MRI}$ after four cycles. Long term follow-up after re-treatment was not available.

Table I: Case Reports and Series of Temozolomide Treatment in Somatotroph Tumors

\begin{tabular}{|c|c|c|c|c|c|c|c|}
\hline Author, year & $\begin{array}{c}\text { Age } \\
\text { (years) }\end{array}$ & Sex & Type & Other treatments & $\begin{array}{l}\text { MGMT status } \\
\text { (IHC) }\end{array}$ & TMZ Dose and cycles & Response \\
\hline $\begin{array}{l}\text { McCormack et al. (43); } \\
2009\end{array}$ & 48 & M & PA & PS, RT, SLA, DA & Positive & $150 \mathrm{mg} / \mathrm{m}^{2}, 3 \mathrm{c}$ & NR \\
\hline Morin et al. (50); 2012 & 22 & M & $\mathrm{PA}$ & PS, RT, Pegvisomant & NA & $200 \mathrm{mg} / \mathrm{m}^{2}, 5 \mathrm{c}$ & NR \\
\hline \multirow[t]{2}{*}{ Batisse et al. (6); 2013} & 47 & M & $\mathrm{PA}$ & $\begin{array}{c}\text { PS, RT, SLA, Cisplatin, } \\
\text { Adriamycin }\end{array}$ & High (90\%) & $200 \mathrm{mg} / \mathrm{m}^{2}, 3 \mathrm{c}$ & NR \\
\hline & 54 & $\mathrm{~F}$ & $\mathrm{PC}$ & PS, RT, SLA & $68 \%$ & $150-200 \mathrm{mg} / \mathrm{m}^{2}, 7 \mathrm{c}$ & $\mathrm{NR}(\mathrm{SD})$ \\
\hline Ghazi et al. (27); 2015 & 39 & $\mathrm{M}$ & PA & PS & Negative & $150 \mathrm{mg} / \mathrm{m}^{2}, 8 \mathrm{c}$ & NR \\
\hline $\begin{array}{l}\text { Bengtsson et al.*(7); } \\
2015\end{array}$ & $\begin{array}{l}31^{\star \star} \\
13^{\star \star} \\
46 \\
40\end{array}$ & $\begin{array}{l}\mathrm{F} \\
\mathrm{F} \\
\mathrm{M} \\
\mathrm{F}\end{array}$ & $\begin{array}{l}\text { PA } \\
\text { PA } \\
P C \\
P C\end{array}$ & $\begin{array}{c}\text { PS, RT, SLA, lomustine } \\
\text { PS, RT, DA, SLA, lomustine } \\
\text { PS, RT, SLA, Pegvisomant } \\
\text { PS, RT, DA }\end{array}$ & $\begin{array}{l}\text { Heterogeneous } \\
\text { High }(95 \%) \\
\text { High }(90 \%) \\
\text { Low }(9 \%)\end{array}$ & $\begin{array}{c}150-200 \mathrm{mg} / \mathrm{m}^{2}, 6 \mathrm{c} \\
150-200 \mathrm{mg} / \mathrm{m}^{2}, \mathrm{NA} \\
150-200 \mathrm{mg} / \mathrm{m}^{2} \\
150-200 \mathrm{mg} / \mathrm{m}^{2}, 6\end{array}$ & $\begin{array}{l}\text { PR } \\
\text { NA } \\
\text { NR } \\
\text { CR }\end{array}$ \\
\hline Losa et al. (41), 2015 & $\begin{array}{l}\text { NA } \\
\text { NA }\end{array}$ & $\begin{array}{l}\text { NA } \\
\text { NA }\end{array}$ & $\begin{array}{l}\text { NA } \\
\text { NA }\end{array}$ & $\begin{array}{l}\text { NA } \\
\text { NA }\end{array}$ & $\begin{array}{l}\text { NA } \\
\text { NA }\end{array}$ & $\begin{array}{l}150-200 \mathrm{mg} / \mathrm{m}^{2}, \mathrm{NA} \\
150-200 \mathrm{mg} / \mathrm{m}^{2}, \mathrm{NA}\end{array}$ & $\begin{array}{l}\text { NR (SD) } \\
\text { NR (SD) }\end{array}$ \\
\hline Our patient & & M & $\mathrm{PA}$ & PS, RT, SLA, Pegvisomant & NA & $200 \mathrm{mg} / \mathrm{m}^{2}, 3 \mathrm{c}$ & NR \\
\hline
\end{tabular}

F: Female, M: Male, PC: Pituitary carcinoma, PA: Pituitary adenoma, PS: Pituitary surgery, RT: Radiotherapy, DA: Dopamine agonist, SLA: Somatostatin ligand antagonist, KNZ: Ketoconazole; NA: Not available, NR: Non-responder, PR: Partial response, CR: Complete response, SD: Stable disease.

*Two patients with prolactinoma with further GH secretion from this series are given in Table III. One of the cases was also reported by Hagen et al. in 2009 (28). **These two patients were previously reported by Asimakopoulou et al. in 2014 (4). 


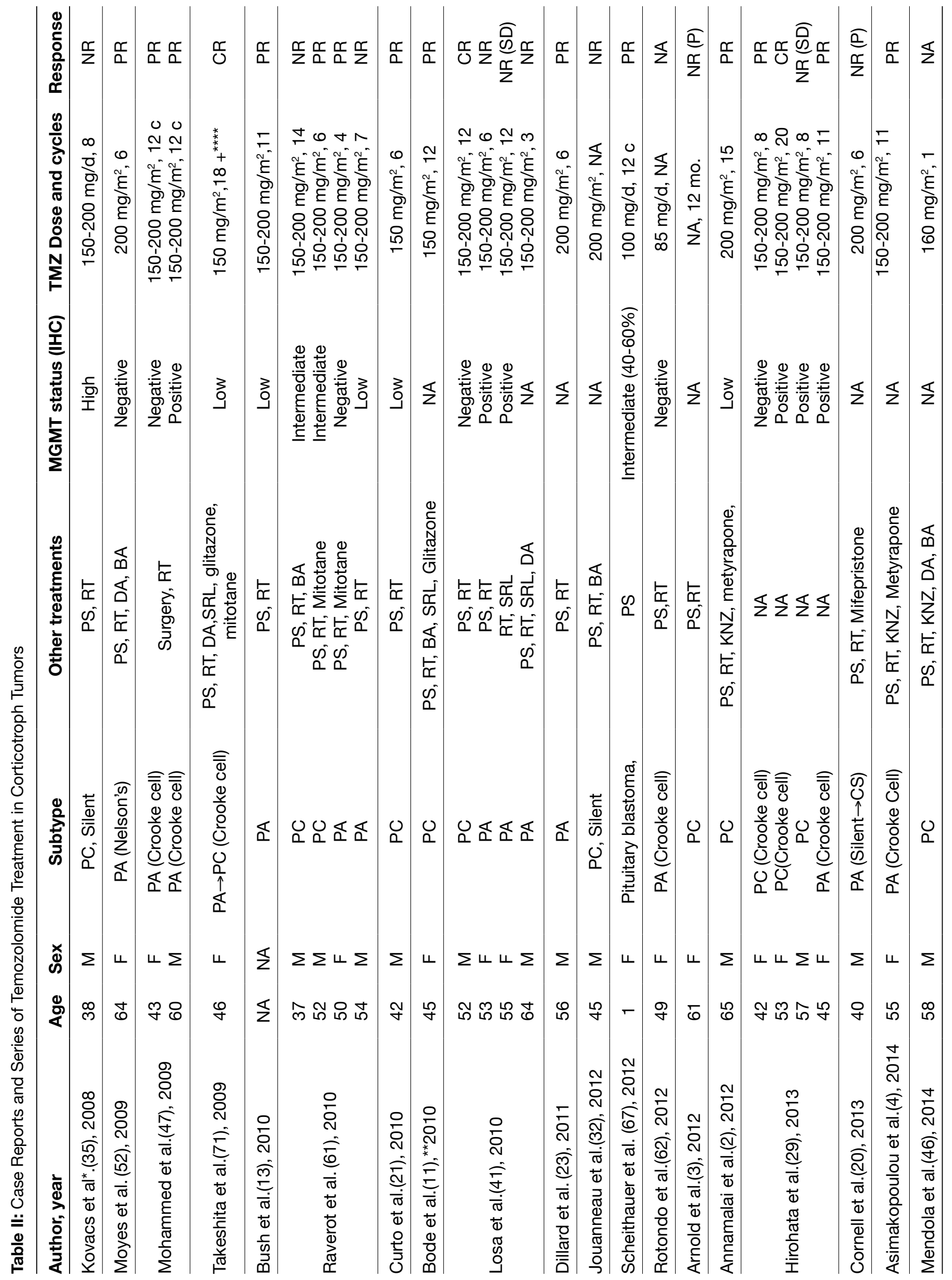




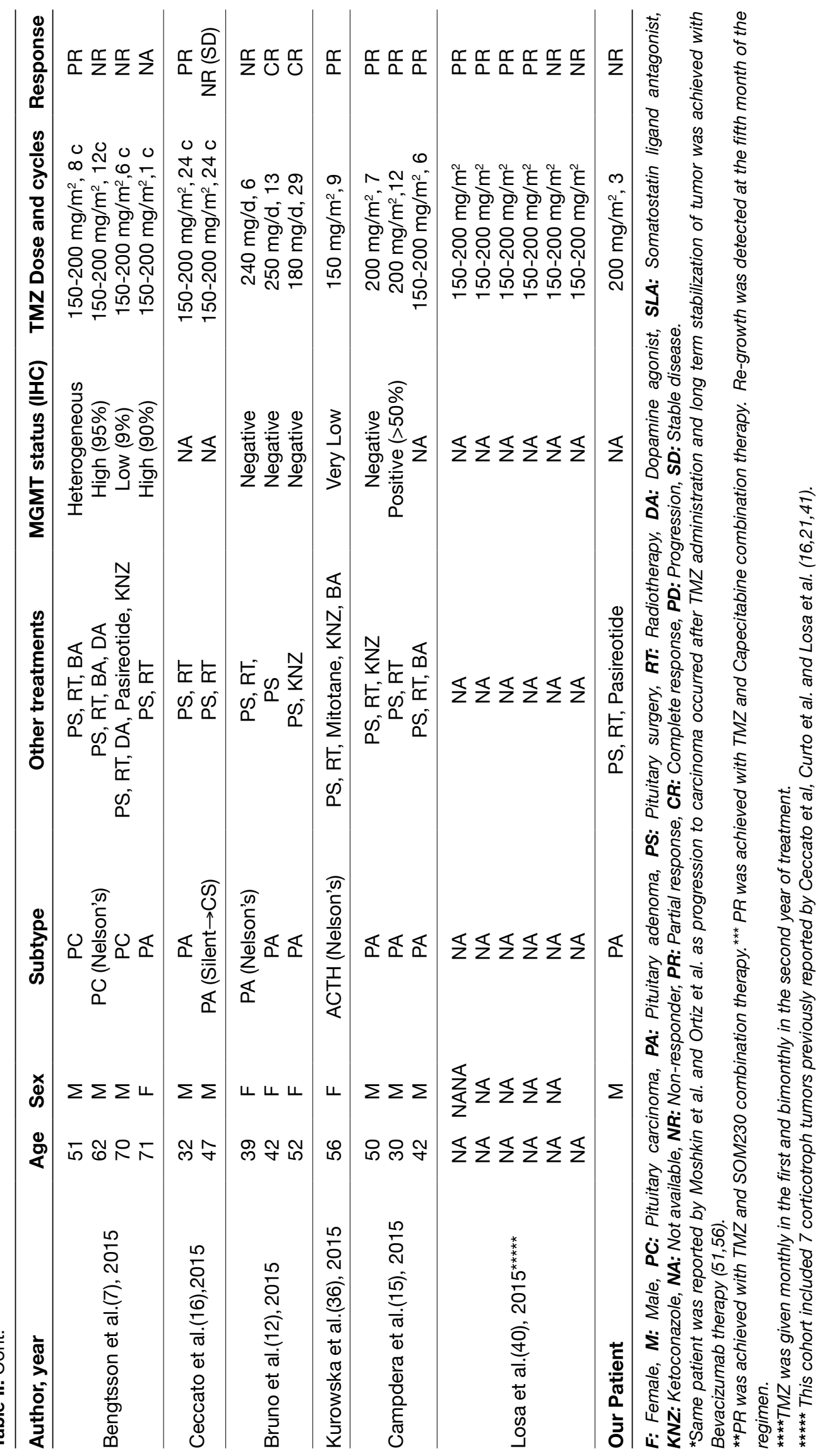


Table III: Case Reports and Series of Temozolomide Treatment in Mammotroph Tumors

\begin{tabular}{|c|c|c|c|c|c|c|c|}
\hline Author, year & $\begin{array}{l}\text { Age } \\
\text { Years }\end{array}$ & Gender & Subtype & Other treatments & $\begin{array}{c}\text { MGMT } \\
\text { status (IHC) }\end{array}$ & $\begin{array}{l}\text { TMZ Dose and } \\
\text { cycles }\end{array}$ & Response \\
\hline Zhu et al.(79), 2004 & 61 & M & PC & NA & NA & NA & PR \\
\hline Syro et al.(70), 2006 & 46 & M & PA & PS, RT, DA & NA & $200 \mathrm{mg} / \mathrm{m}^{2} / \mathrm{d}, 7$ & $\mathrm{PR}$ \\
\hline Fadul et al.(24), 2006 & 36 & M & PC & $\begin{array}{c}\text { PS, RT, DA, SLA, } \\
\text { Carboplatin, } \\
\text { Paclitaxel, } \\
\text { Etoposide }\end{array}$ & NA & $200 \mathrm{mg} / \mathrm{m}^{2} / \mathrm{d}, 10$ & PR \\
\hline Lim et al.(38), 2006 & 77 & M & $\mathrm{PC}$ & PS, RT, DA, & NA & $200 \mathrm{mg} / \mathrm{m}^{2} / \mathrm{d}, 18$ & PR \\
\hline Neff et al.(54), 2007 & 52 & $\mathrm{~F}$ & PA & PS, RT, DA, SLA & NA & $150 \mathrm{mg} / \mathrm{m}^{2} / \mathrm{d}, 26$ & PR \\
\hline Kovacs et al.(34), 2007 & 46 & M & $\mathrm{PC}$ & PS, RT, DA & NA & $200 \mathrm{mg} / \mathrm{m}^{2}, 7$ & PR \\
\hline Debono et al.(22), 2008 & 47 & M & PA (MEN1) & PS, RT, DA & Low & $150-200$ mg/m², 11 & $\mathrm{PR}$ \\
\hline $\begin{array}{l}\text { Hagen et al.(28), } 2009 \\
\text { Bengtsson et al.(7), } 2015\end{array}$ & $\begin{array}{l}60 \\
49 \\
\end{array}$ & $\begin{array}{l}\mathrm{M} \\
\mathrm{F}\end{array}$ & $\begin{array}{c}\mathrm{PA} \\
\mathrm{PC}(+\mathrm{GH}) \\
\end{array}$ & $\begin{array}{c}\text { PS, DA, SLA } \\
\text { PS, RT, DA, SLA }\end{array}$ & $\begin{array}{l}\text { Low }(9 \%) \\
\text { Low }(9 \%)\end{array}$ & $\begin{array}{r}150-200 \mathrm{mg}, 12 \\
150-200 \mathrm{mg}, 23\end{array}$ & $\begin{array}{l}\mathrm{PR} \\
\mathrm{CR}\end{array}$ \\
\hline $\begin{array}{l}\text { McCormack et al.(43), } \\
2009\end{array}$ & 65 & $\mathrm{~F}$ & PC & PS, RT, DA, SLA & Negative & $200 \mathrm{mg} / \mathrm{m}^{2}, 4$ & PR \\
\hline Byrne et al.(14), 2009 & 64 & M & PC & PS, DA & NA & $200 \mathrm{mg} / \mathrm{m}^{2}, 12$ & PR \\
\hline Losa et al.(41), 2010 & $\begin{array}{l}62 \\
57 \\
\end{array}$ & $\begin{array}{l}\mathrm{M} \\
\mathrm{F}\end{array}$ & $\begin{array}{l}\text { PA } \\
\text { PA }\end{array}$ & $\begin{array}{l}\text { PS, RT, DA } \\
\text { PS, RT, DA }\end{array}$ & $\begin{array}{c}\text { Negative } \\
N^{\star * \star}\end{array}$ & $\begin{array}{l}200 \mathrm{mg} / \mathrm{m}^{2}, 12 \\
200 \mathrm{mg} / \mathrm{m}^{2}, 12\end{array}$ & $\begin{array}{l}\text { NR (SD) } \\
\text { PR }\end{array}$ \\
\hline Raverot et al.(61), 2010 & $\begin{array}{l}43 \\
71 \\
69 \\
47 \\
\end{array}$ & $\begin{array}{c}M \\
M \\
M \\
F\end{array}$ & $\begin{array}{l}P C \\
P A \\
P C \\
P C\end{array}$ & $\begin{array}{l}\text { PS,RT, DA } \\
\text { PS,RT, DA } \\
\text { PS,RT, DA } \\
\text { PS,RT, DA }\end{array}$ & $\begin{array}{c}\text { NA } \\
30 \% \\
\text { Negative } \\
100 \%\end{array}$ & $\begin{array}{c}150-200 \mathrm{mg} / \mathrm{m}^{2}, 24 \\
150-200 \mathrm{mg} / \mathrm{m}^{2}, 8 \\
150-200 \mathrm{mg} / \mathrm{m}^{2}, 5 \\
150-200 \mathrm{mg} / \mathrm{m}^{2}, 3\end{array}$ & $\begin{array}{l}\text { PR } \\
\text { NR } \\
\text { NR } \\
\text { NR }\end{array}$ \\
\hline Bush et al.(13), 2010 & NA & NA & PA & NA & Low $(<10 \%)$ & 75 mg (21/7), 11 & PR \\
\hline Murakami et al.(53), 2011 & 60 & $\mathrm{~F}$ & PA & PS, RT, DA & Negative & $200 \mathrm{mg} / \mathrm{m}^{2}, 10$ & $\mathrm{PR}$ \\
\hline Phillips et al.(58), 2012 & 28 & M & PC (MEN1) & PS, RT, DA & NA & $350 \mathrm{mg}, 1$ & NR \\
\hline Phillipon et al.(57), 2012 & 41 & M & PA (MEN1) & PS, RT, DA & NA & 200 mg/m², 24 & PR \\
\hline Whitelaw et al.(73), 2012 & $\begin{array}{l}39 \\
32 \\
15 \\
\end{array}$ & $\begin{array}{l}M \\
M \\
M\end{array}$ & $\begin{array}{l}\text { PA } \\
\text { PA } \\
\text { PA }\end{array}$ & $\begin{array}{c}\text { PS, RT, DA } \\
\text { PS, DA } \\
\text { PS, DA }\end{array}$ & $\begin{array}{l}\text { Negative } \\
\text { Negative } \\
\text { Negative }\end{array}$ & $\begin{array}{l}200 \mathrm{mg} / \mathrm{m}^{2}, 6 \\
200 \mathrm{mg} / \mathrm{m}^{2}, 6 \\
200 \mathrm{mg} / \mathrm{m}^{2}, 12\end{array}$ & $\begin{array}{l}\text { PR } \\
P R \\
P R\end{array}$ \\
\hline Chentli et al.(18), 2013 & 27 & $\mathrm{~F}$ & PA & PS, DA, SLA & NA & $5 \mathrm{mg} / \mathrm{d}$ & $\mathrm{PR}$ \\
\hline Hirohata et al.(29), 2013 & $\begin{array}{l}66 \\
49 \\
60 \\
60 \\
60\end{array}$ & $\begin{array}{l}\mathrm{F} \\
\mathrm{F} \\
\mathrm{M} \\
\mathrm{F} \\
\mathrm{F}\end{array}$ & $\begin{array}{l}\text { PA } \\
\text { PA } \\
P C \\
P C \\
P C\end{array}$ & $\begin{array}{l}\text { NA } \\
\text { NA } \\
\text { NA } \\
\text { NA } \\
\text { NA }\end{array}$ & $\begin{array}{l}\text { Negative } \\
\text { Negative } \\
\text { Negative } \\
\text { Positive } \\
\text { Negative }\end{array}$ & $\begin{array}{c}150-200 \mathrm{mg} / \mathrm{m}^{2}, 20 \\
150-200 \mathrm{mg} / \mathrm{m}^{2}, 3 \\
150-200 \mathrm{mg} / \mathrm{m}^{2}, 24 \\
150-200 \mathrm{mg} / \mathrm{m}^{2}, 12 \\
150-200 \mathrm{mg} / \mathrm{m}^{2}, 10\end{array}$ & $\begin{array}{c}\text { CR } \\
\text { NR(P) } \\
\text { PR } \\
\text { PR } \\
\text { CR }\end{array}$ \\
\hline Zemmoura et al.(77), 2013 & 54 & M & PC & PS, RT,DA & NA & $200 \mathrm{mg} / \mathrm{m}^{2}, 5$ & NR \\
\hline
\end{tabular}


Table III: Cont.

\begin{tabular}{|c|c|c|c|c|c|c|c|}
\hline Author,year & $\begin{array}{l}\text { Age } \\
\text { Years }\end{array}$ & Gender & Subtype & Other treatments & $\begin{array}{c}\text { MGMT } \\
\text { status (IHC) }\end{array}$ & $\begin{array}{l}\text { TMZ Dose and } \\
\text { cycles }\end{array}$ & Response \\
\hline \multirow{6}{*}{ Bengtsson et al.(7), 2015} & 33 & $M^{\star *}$ & $\mathrm{PA}(+\mathrm{GH})$ & PS, DA, SLA & Low (10\%) & $150-200 \mathrm{mg} / \mathrm{m}^{2}, 3$ & PR \\
\hline & 34 & M & PA & PS, RT, DA & $\begin{array}{c}\text { Intermediate } \\
(9-100)\end{array}$ & $150-200 \mathrm{mg} / \mathrm{m}^{2}, 3$ & $P R^{*}$ \\
\hline & 45 & M & PA & $\begin{array}{l}\text { PS, RT, DA, } \\
\text { Lomustine }\end{array}$ & High (100\%) & $150-200 \mathrm{mg} / \mathrm{m}^{2}, 18$ & NR \\
\hline & 68 & M & PA & PS, DA & Low (9\%) & $150-200 \mathrm{mg} / \mathrm{m}^{2}, 1$ & NA \\
\hline & 23 & M & PA & $\begin{array}{l}\text { PS, RT, DA, SLA, } \\
\text { Pasireotide }\end{array}$ & High (100\%) & $150-200 \mathrm{mg} / \mathrm{m}^{2}, 4$ & NR \\
\hline & & & PC & PS, RT, DA, SLA & $\begin{array}{l}\text { Intermediate } \\
(50 \%)\end{array}$ & $150-200$ mg/m², 14 & \\
\hline Bruno et al.(12), 2015 & 78 & M & $\mathrm{PC}$ & PS, RT, DA & Negative & $140 \mathrm{mg} / \mathrm{d}, 1 \mathrm{c}$ & NA \\
\hline Strowd et al.(69), 2015 & 44 & $\mathrm{~F}$ & PA & PS, RT, DA & NA & $150-200 \mathrm{mg} / \mathrm{m}^{2}, 3$ & PR \\
\hline \multirow{3}{*}{ Losa et al.(40), ${ }^{\star \star \star \star} 2015$} & NA & NA & NA & NA & NA & $150-200 \mathrm{mg} / \mathrm{m}^{2}$ & PR \\
\hline & NA & NA & NA & NA & NA & $150-200 \mathrm{mg} / \mathrm{m}^{2}$ & $N R(S D)$ \\
\hline & NA & NA & NA & NA & NA & $150-200 \mathrm{mg} / \mathrm{m}^{2}$ & NR \\
\hline Our patient & 65 & $\mathrm{~F}$ & PA & PS, RT, DA & NA & $200 \mathrm{mg} / \mathrm{m}^{2}, 6$ & PR \\
\hline
\end{tabular}

F: Female, M: Male, PC: Pituitary carcinoma, PA: Pituitary adenoma, PS: Pituitary surgery, RT: Radiotherapy, DA: Dopamine agonist, SLA: Somatostatine ligand antagonist, NA: Not available, NR: Non-responder, PR: Partial response, CR: Complete response, PD: Progression, SD: Stable disease, MEN1: Multiple Endocrine Neoplasia Type 1.

*Stable tumor, PRL normalized at follow-up.

**This patient was previously reported by Asimakopoulou et al. in 2014 (4).

${ }^{* * *}$ Completely negative staining of tumor but also negative control.

****This cohort included 2 mammotroph tumors previously reported by Losa et al.(40).

According to all reported cases, the overall response rates to $\mathrm{TMZ}$ in prolactinoma, corticotropinoma and somatostatinoma are $67.3 \%, 60 \%$ and $26.7 \%$ respectively. Previously, $\mathrm{TMZ}$ responsiveness was reported in $60 \%$ of aggressive adenomas and $69 \%$ of PCs (60). A subsequent review of the four cohorts revealed $55.5 \%$ and $41 \%$ partial response in aggressive adenomas and PCs (65). Even with such analyses indicating a $T M Z$ response rate, the efficacy of $T M Z$ in pituitary tumors is not easy to establish because of distinct response criteria and limited clinical trials. A recent case series defined complete response as complete regression of tumor mass and normalization of hormone levels. Decrease in tumor volume $\geq 30 \%$ and/or hormone concentrations $\geq 50 \%$ were accepted as partial response (7). They reported partial response in 6 of 13 evaluable patients with locally aggressive adenomas treated with TMZ. Another study from Japan classified effectiveness of $\mathrm{TMZ}$ according to Response Evaluation Criteria in Solid Tumors (RECIST) version 2.0. Complete response was defined as disappearance of target lesion and partial response was defined as $\geq 30 \%$ decrease in the sum of diameters of the target lesion (29). Decrease in hormone concentrations was not included in these response criteria. They achieved complete or partial response in 10 out of 13 subjects but noted that recurrence occurred in 6 (46\%) patients after an effective response. As mentioned above, a patient who was accepted as a responder may be a non-responder according to different criteria or vice versa. Also, it is not clear whether or not patients with stable tumors should be accepted as responders. A recent analysis of Italian patients who were treated with $\mathrm{TMZ}$ revealed disease control in $25 / 31$ (80.6 \%) of cases when stable tumors were included. However, reduction of tumor size or hormonal normalization was achieved only in $35.5 \%$ and $28.6 \%$ of the patients, respectively (40). Moreover, the reported response rates might have been overestimated due to more frequent reporting of responders than non-responders as well. Therefore, an uniform description of response criteria is needed for reliable evaluation of TMZ responsiveness.

MGMT immunoexpression status is the most commonly studied factor affecting TMZ responsiveness. Immunohistochemistry is the preferred method for detection of MGMT status in pituitary tumors (43). In 2008, Kovasc et al. suggested a relationship between TMZ responsiveness and MGMT status (35). McCormack et al. and Whitelaw et al. observed a significant association between MGMT negative tumor staining 
and favorable response to TMZ $(43,73)$. Recently, Bengtsson et al. demonstrated lower MGMT immunoexpression in TMZ responders compared to non-responders (median 9\% vs. $93 \%, \mathrm{p}<0.01$ ) and concluded that a MGMT level below $50 \%$ was a predictor of response to TMZ (7). Conversely, two studies reported resistance to TMZ in MGMT negative PCs although they achieved response in tumors with only low to moderate MGMT expression $(13,61)$. These results indicate that additional factors are related with the efficacy of $T M Z$ treatment. Resistance to TMZ due to DNA mismatch repair protein (MSH6) mutation was also reported in APAs and PCs (29). However, the impact of these mutations as predictors of the response to TMZ is not well-established and routine immunohistochemical assessment of MGMT or MSH is not recommended.

Biochemical and radiological assessment is recommended after three cycles of temozolomide treatment (61). If there is no response, resistance to drug is indicated. Further progression or unresponsiveness was also reported in initial TMZ responders. Intensified TMZ regimens were proposed to lower MGMT expression but this finding was not confirmed in pituitary adenomas (74). Sensitization of glioblastoma cells to TMZ effect by Disulfiram was demonstrated (78). Zhao et al. observed that Disulfiram sensitized pituitary adenoma cells to $T M Z$ in vitro by reducing MGMT protein expression. Down-regulation of MGMT expression with HIF-1a (Hypoxia-inducible factor 1a) was suggested as a potential method to improve TMZ sensitization (17). Unfortunately clinical data about these potential methods is not available yet. Alternative treatment options for TMZ resistant tumors include TMZ-pasireotide and TMZ-capecitabine combinations (16). Successful treatment of aggressive Cushing Disease with the CAPTEM protocol (Capecitabine and TMZ combination) was reported in case reports and a recent small case series $(61,75)$. Target of rapamycin inhibitor (everolimus), and targeted therapies (anti-vascular endothelial growth factor, epidermal growth factor receptor), were also reported on a case report basis $(37,41,56)$.

\section{CONCLUSION}

Approximately $50 \%$ of aggressive pituitary adenomas and carcinomas are responsive to TMZ. However, uniformly defined response criteria and relevant durations of response are still lacking. Clinical trials are also needed to identify treatment regimens for $\mathrm{TMZ}$ resistant pituitary tumors.

\section{REFERENCES}

1. Al-Shraim M, Asa SL: The 2004 World Health Organization classification of pituitary tumors: What is new? Acta Neuropathol 111:1-7, 2006

2. Annamalai AK, Dean AF, Kandasamy N, Kovacs $K$, Burton $H$, Halsall DJ, Shaw AS, Antoun NM, Cheow HK, Kirollos RW, Pickard JD, Simpson HL, Jefferies SJ, Burnet NG, Gurnell M: Temozolomide responsiveness in aggressive corticotroph tumours: A case report and review of the literature. Pituitary 15:276-287, 2012
3. Arnold PM, Ratnasingam D, O'Neil MF, Johnson PL: Pituitary carcinoma recurrent to the lumbar intradural extramedullary space: Case report. J Spinal Cord Med 35:118-121, 2012

4. Asimakopoulou A, Tzanela M, Koletti A, Kontogeorgos G, Tsagarakis S: Long-term remission in an aggressive Crooke cell adenoma of the pituitary, 18 months after discontinuation of treatment with temozolomide. Clin Case Rep 2:1-3, 2014

5. Baker SD, Wirth M, Statkevich P, Reidenberg P, Alton K, Sartorius SE, Dugan M, Cutler D, Batra V, Grochow LB, Donehower RC, Rowinsky EK: Absorption, metabolism, and excretion of 14C-temozolomide following oral administration to patients with advanced cancer. Clin Cancer Res 5:309-317, 1999

6. Batisse M, Raverot G, Maqdasy S, Durando X, Sturm N, Montoriol PF, Kemeny JL, Chazal J, Trouillas J, Tauveron I: Aggressive silent GH pituitary tumor resistant to multiple treatments, including temozolomide. Cancer Invest 31:190196, 2013

7. Bengtsson D, Schroder HD, Andersen M, Maiter D, Berinder K, Feldt Rasmussen U, Rasmussen AK, Johannsson G, Hoybye C, van der Lely AJ, Petersson M, Ragnarsson O, Burman P: Long-term outcome and MGMT as a predictive marker in 24 patients with atypical pituitary adenomas and pituitary carcinomas given treatment with temozolomide. J Clin Endocrinol Metab 100:1689-1698, 2015

8. Besser GM, Burman P, Daly AF: Predictors and rates of treatment-resistant tumor growth in acromegaly. Eur $\mathrm{J}$ Endocrinol 153:187-193, 2005

9. Biller BM, Grossman AB, Stewart PM, Melmed S, Bertagna X, Bertherat J, Buchfelder M, Colao A, Hermus AR, Hofland LJ, Klibanski A, Lacroix A, Lindsay JR, Newell-Price J, Nieman LK, Petersenn S, Sonino N, Stalla GK, Swearingen B, Vance ML, Wass JA, Boscaro M: Treatment of adrenocorticotropindependent Cushing's syndrome: A consensus statement. J Clin Endocrinol Metab 93:2454-2462, 2008

10. Blevins LS Jr, Christy JH, Khajavi M, Tindall GT: Outcomes of therapy for Cushing's disease due to adrenocorticotropinsecreting pituitary macroadenomas. J Clin Endocrinol Metab 83:63-67, 1998

11. Bode H, Seiz M, Lammert A, Brockmann MA, Back W, Hammes HP, Thome C: SOM230 (pasireotide) and temozolomide achieve sustained control of tumour progression and ACTH secretion in pituitary carcinoma with widespread metastases. Exp Clin Endocrinol Diabetes 118:760-763, 2010

12. Bruno OD, Juarez-Allen L, Christiansen SB, Manavela M, Danilowicz K, Vigovich C, Gomez RM: Temozolomide therapy for aggressive pituitary tumors: Results in a small series of patients from Argentina. Int J Endocrinol 2015:587893, 2015

13. Bush ZM, Longtine JA, Cunningham T, Schiff D, Jane JA Jr, Vance ML, Thorner MO, Laws ER Jr, Lopes MB: Temozolomide treatment for aggressive pituitary tumors: Correlation of clinical outcome with O(6)-methylguanine methyltransferase (MGMT) promoter methylation and expression. J Clin Endocrinol Metab 95:E280-290, 2010

14. Byrne $\mathrm{S}$, Karapetis $\mathrm{C}$, Vrodos $\mathrm{N}$ : A novel use of temozolomide in a patient with malignant prolactinoma. J Clin Neurosci 16:1694-1696, 2009 
15. Campdera M, Palacios N, Aller J, Magallon R, Martin P, Saucedo G, Lilienfeld H, Estrada J: Temozolomide for aggressive ACTH pituitary tumors: Failure of a second course of treatment. Pituitary 19(2):158-166, 2016

16. Ceccato F, Lombardi G, Manara R, Emanuelli E, Denaro L, Milanese L, Gardiman MP, Bertorelle R, Scanarini M, D'Avella D, Occhi G, Boscaro M, Zagonel V, Scaroni C: Temozolomide and pasireotide treatment for aggressive pituitary adenoma: Expertise at a tertiary care center. J Neurooncol 122:189-196, 2015

17. Chen W, Xiao Z, Zhao Y, Huang L, Du G: HIF-1alpha inhibition sensitizes pituitary adenoma cells to temozolomide by regulating MGMT expression. Oncol Rep 30:2495-2501, 2013

18. Chentli F, Yaker FA, Azzoug S, Belhimer F: Temozolomide: Anti-tumor effect on giant, invasive and resistant pediatric prolactinoma. Indian J Endocrinol Metab 17:1136-1138, 2013

19. Ciric I, Zhao JC, Du H, Findling JW, Molitch ME, Weiss RE, Refetoff S, Kerr WD, Meyer J: Transsphenoidal surgery for Cushing disease: Experience with 136 patients. Neurosurgery 70:70-80; discussion 80-71, 2012

20. Cornell RF, Kelly DF, Bordo G, Carroll TB, Duong HT, Kim J, Takasumi Y, Thomas JP, Wong YL, Findling JW: Chemotherapy-induced regression of an adrenocorticotropinsecreting pituitary carcinoma accompanied by secondary adrenal insufficiency. Case Rep Endocrinol 2013:675298, 2013

21. Curto L, Torre ML, Ferrau F, Pitini V, Altavilla G, Granata F, Longo M, Hofland LJ, Trimarchi F, Cannavo S: Temozolomideinduced shrinkage of a pituitary carcinoma causing Cushing's disease-Report of a case and literature review. Scientific World Journal 10:2132-2138, 2010

22. Debono M, Bridgewater C, Ross R, Newell-Price J: Treating an aggressive prolactinoma in a patient with MEN 1: Beneficial response to temozolomide. Society for Endocrinology BES; Endocrine Abstracts, 15:188, 2008

23. Dillard TH, Gultekin SH, Delashaw JB Jr, Yedinak CG, Neuwelt EA, Fleseriu M: Temozolomide for corticotroph pituitary adenomas refractory to standard therapy. Pituitary 14:80-91, 2011

24. Fadul CE, Kominsky AL, Meyer LP, Kingman LS, Kinlaw WB, Rhodes $\mathrm{CH}$, Eskey CJ, Simmons NE: Long-term response of pituitary carcinoma to temozolomide. Report of two cases. J Neurosurg 105:621-626, 2006

25. Fernandez A, Karavitaki N, Wass JA: Prevalence of pituitary adenomas: A community-based, cross-sectional study in Banbury (Oxfordshire, UK). Clin Endocrinol 72:377-382, 2010

26. George DH, Scheithauer BW, Kovacs K, Horvath E, Young WF Jr, Lloyd RV, Meyer FB: Crooke's cell adenoma of the pituitary: An aggressive variant of corticotroph adenoma. Am J Surg Pathol 27:1330-1336, 2003

27. Ghazi AA, Rotondo F, Kovacs K, Amirbaigloo A, Syro LV, Fathalla $H$, Di leva A, Cusimano MD: Treatment of invasive silent somatotroph pituitary adenoma with temozolomide. Report of a case and review of the literature. Endocr Pathol 26:135-139, 2015
28. Hagen C, Schroeder HD, Hansen S, Hagen C, Andersen M: Temozolomide treatment of a pituitary carcinoma and two pituitary macroadenomas resistant to conventional therapy. Eur J Endocrinol 161:631-637, 2009

29. Hirohata T, Asano K, Ogawa Y, Takano S, Amano K, Isozaki O, Iwai Y, Sakata K, Fukuhara N, Nishioka H, Yamada S, Fujio S, Arita K, Takano K, Tominaga A, Hizuka N, Ikeda H, Osamura RY, Tahara S, Ishii Y, Kawamata T, Shimatsu A, Teramoto A, Matsuno A: DNA mismatch repair protein (MSH6) correlated with the responses of atypical pituitary adenomas and pituitary carcinomas to temozolomide: The national cooperative study by the Japan Society for Hypothalamic and Pituitary Tumors. $\mathrm{J}$ Clin Endocrinol Metab 98:1130-1136, 2013

30. Hirohata T, Ishii Y, Matsuno A: Treatment of pituitary carcinomas and atypical pituitary adenomas: A review. Neurol Med Chir 54:966-973, 2014

31. Hurel SJ, Harris PE, McNicol AM, Foster S, Kelly WF, Baylis $\mathrm{PH}$ : Metastatic prolactinoma: Effect of octreotide, cabergoline, carboplatin and etoposide; immunocytochemical analysis of proto-oncogene expression. J Clin Endocrinol Metab 82:2962-2965, 1997

32. Jouanneau E, Wierinckx A, Ducray F, Favrel V, Borson-Chazot F, Honnorat J, Trouillas J, Raverot G: New targeted therapies in pituitary carcinoma resistant to temozolomide. Pituitary 15:37-43, 2012

33. Kaltsas GA, Evanson J, Chrisoulidou A, Grossman AB: The diagnosis and management of parasellar tumours of the pituitary. Endocr Relat Cancer 15:885-903, 2008

34. Kovacs K, Horvath E, Syro LV, Uribe H, Penagos LC, Ortiz LD, Fadul CE: Temozolomide therapy in a man with an aggressive prolactin-secreting pituitary neoplasm: Morphological findings. Human Pathol 38:185-189, 2007

35. Kovacs K, Scheithauer BW, Lombardero M, McLendon RE, Syro LV, Uribe H, Ortiz LD, Penagos LC: MGMT immunoexpression predicts responsiveness of pituitary tumors to temozolomide therapy. Acta Neuropathol 115:261-262, 2008

36. Kurowska M, Nowakowski A, Zielinski G, Malicka J, Tarach JS, Maksymowicz M, Denew P: Temozolomide-induced shrinkage of invasive pituitary adenoma in patient with Nelson's Syndrome: A case report and review of the literature. Case Rep Endocrinol 2015:623092, 2015

37. Laws ER Jr, Morris AM, Maartens N: Gliadel for pituitary adenomas and craniopharyngiomas. Neurosurgery 53:255269; discussion 259-260, 2003

38. Lim S, Shahinian H, Maya MM, Yong W, Heaney AP: Temozolomide: A novel treatment for pituitary carcinoma. Lancet Oncol 7:518-520, 2006

39. Lloyd RV KK YWJ, Farrel WE, Asa SL, Truillas J, Kontogeorgos G, Sano T, Scheithauer BW, Horvath E, DeLellis RA, Heitz PU: Pituitary tumors. In: DeLellis R, Lloyd R, Heitz P, Eng C (eds). WHO Classification of Tumors of the Endocrine Organs: Pathology and Genetics of Endocrine Organs. 2004

40. Losa M, Bogazzi F, Cannavo S, Ceccato F, Curto L, De Marinis L, lacovazzo D, Lombardi G, Mantovani G, Mazza E, Minniti G, Nizzoli M, Reni M, Scaroni C: Temozolomide therapy in patients with aggressive pituitary adenomas or carcinomas. J Neurooncol 126(3):519-525, 2016 
41. Losa M, Mazza E, Terreni MR, McCormack A, Gill AJ, Motta M, Cangi MG, Talarico A, Mortini P, Reni M: Salvage therapy with temozolomide in patients with aggressive or metastatic pituitary adenomas: Experience in six cases. Eur $\mathrm{J}$ Endocrinol 163:843-851, 2010

42. Marchesi F, Turriziani M, Tortorelli G, Avvisati G, Torino F, De Vecchis L: Triazene compounds: Mechanism of action and related DNA repair systems. Pharmacol Res 56:275-287, 2007

43. McCormack Al, McDonald KL, Gill AJ, Clark SJ, Burt MG, Campbell KA, Braund WJ, Little NS, Cook RJ, Grossman $A B$, Robinson BG, Clifton-Bligh RJ: Low O6-methylguanineDNA methyltransferase (MGMT) expression and response to temozolomide in aggressive pituitary tumours. Clin Endocrinol 71:226-233, 2009

44. Melmed S: Acromegaly pathogenesis and treatment. J Clin Invest 119:3189-3202, 2009

45. Melmed S, Casanueva FF, Hoffman AR, Kleinberg DL, Montori VM, Schlechte JA, Wass JA; Endocrine Society: Diagnosis and treatment of hyperprolactinemia: An Endocrine Society clinical practice guideline. J Clin Endocrinol Metab 96:273288, 2011

46. Mendola M, Passeri E, Ambrosi B, Corbetta S: Multiple cerebral hemorrhagic foci from metastases during temozolomide treatment in a patient with corticotroph pituitary carcinoma. J Clin Endocrinol Metab 99:2623-2624, 2014

47. Mohammed S, Kovacs K, Mason W, Smyth H, Cusimano MD: Use of temozolomide in aggressive pituitary tumors: Case report. Neurosurgery 64:E773-774; discussion E774, 2009

48. Molitch ME: Management of medically refractory prolactinoma. J Neurooncol 117:421-428, 2014

49. Molitch ME: The cabergoline-resistant prolactinoma patient: New challenges. J Clin Endocrinol Metab 93:4643-4645, 2008

50. Morin E, Berthelet F, Weisnagel J, Bidlingmaier M, Serri $O$ : Failure of temozolomide and conventional doses of pegvisomant to attain biochemical control in a severe case of acromegaly. Pituitary 15:97-100, 2012

51. Moshkin O, Syro LV, Scheithauer BW, Ortiz LD, Fadul CE, Uribe H, Gonzalez R, Cusimano M, Horvath E, Rotondo F, Kovacs $\mathrm{K}$ : Aggressive silent corticotroph adenoma progressing to pituitary carcinoma: The role of temozolomide therapy. Hormones 10:162-167, 2011

52. Moyes VJ, Alusi G, Sabin HI, Evanson J, Berney DM, Kovacs K, Monson JP, Plowman PN, Drake WM: Treatment of Nelson's syndrome with temozolomide. Eur J Endocrinol 160:115-119, 2009

53. Murakami M, Mizutani A, Asano S, Katakami H, Ozawa $Y$, Yamazaki K, Ishida Y, Takano K, Okinaga H, Matsuno A: A mechanism of acquiring temozolomide resistance during transformation of atypical prolactinoma into prolactinproducing pituitary carcinoma: Case report. Neurosurgery 68:E1761-1767; discussion E1767, 2011

54. Neff LM, Weil M, Cole A, Hedges TR, Shucart W, Lawrence D, Zhu JJ, Tischler AS, Lechan RM: Temozolomide in the treatment of an invasive prolactinoma resistant to dopamine agonists. Pituitary 10:81-86, 2007

55. Nomikos P, Buchfelder M, Fahlbusch R: The outcome of surgery in 668 patients with acromegaly using current criteria of biochemical 'cure'. Eur J Endocrinol 152:379-387, 2005
56. Ortiz LD, Syro LV, Scheithauer BW, Ersen A, Uribe H, Fadul CE, Rotondo F, Horvath E, Kovacs K: Anti-VEGF therapy in pituitary carcinoma. Pituitary 15:445-449, 2012

57. Philippon M, Morange I, Barrie M, Barlier A, Taieb D, Dufour $\mathrm{H}$, Conte-Devolx B, Brue T, Castinetti F: Long-term control of a MEN1 prolactin secreting pituitary carcinoma after temozolomide treatment. Ann Endocrinol (Paris) 73:225-229, 2012

58. Phillips J, East HE, French SE, Melcescu E, Hamilton RD, Nicholas WC, Fratkin JF, Parent AD, Luzardo G, Koch CA: What causes a prolactinoma to be aggressive or to become a pituitary carcinoma? Hormones 11:477-482, 2012

59. Plotz CM, Knowlton Al, Ragan C: The natural history of Cushing's syndrome. Am J Med 13:597-614, 1952

60. Raverot G, Castinetti F, Jouanneau E, Morange I, FigarellaBranger D, Dufour H, Trouillas J, Brue T : Pituitary carcinomas and aggressive pituitary tumours: Merits and pitfalls of temozolomide treatment. Clin Endocrinol 76:769-775, 2012

61. Raverot G, Sturm N, de Fraipont F, Muller M, Salenave S, Caron P, Chabre O, Chanson P, Cortet-Rudelli C, Assaker R, Dufour H, Gaillard S, Francois P, Jouanneau E, Passagia JG, Bernier M, Cornelius A, Figarella-Branger D, Trouillas J, Borson-Chazot F, Brue T: Temozolomide treatment in aggressive pituitary tumors and pituitary carcinomas: A French multicenter experience. J Clin Endocrinol Metab 95:4592-4599, 2010

62. Rotondo F, Cusimano M, Scheithauer BW, Coire C, Horvath E, Kovacs K: Atypical, invasive, recurring Crooke cell adenoma of the pituitary. Hormones 11:94-100, 2012

63. Saeger W, Ludecke DK, Buchfelder M, Fahlbusch R, Quabbe HJ, Petersenn S: Pathohistological classification of pituitary tumors: 10 years of experience with the German Pituitary Tumor Registry. Eur J Endocrinol 156:203-216, 2007

64. Salehi F, Scheithauer BW, Kovacs K, Horvath E, Syro LV, Sharma S, Manoranjan B, Cusimano M: O-6-methylguanineDNA methyltransferase (MGMT) immunohistochemical expression in pituitary corticotroph adenomas. Neurosurgery 70:491-496; discussion 496, 2012

65. Salehi F, Scheithauer BW, Kros JM, Lau Q, Fealey M, Erickson D, Kovacs K, Horvath E, Lloyd RV: MGMT promoter methylation and immunoexpression in aggressive pituitary adenomas and carcinomas. J Neurooncol 104:647-657, 2011

66. Salehi F, Scheithauer BW, Moyes VJ, Drake WM, Syro LV, Manoranjan B, Sharma S, Horvath E, Kovacs K: Low immunohistochemical expression of MGMT in ACTH secreting pituitary tumors of patients with Nelson syndrome. Endocr Pathol 21:227-229, 2010

67. Scheithauer BW, Horvath E, Abel TW, Robital Y, Park SH, Osamura RY, Deal C, Lloyd RV, Kovacs K: Pituitary blastoma: A unique embryonal tumor. Pituitary 15:365-373, 2012

68. Scheithauer BW, Kurtkaya-Yapicier O, Kovacs KT, Young WF Jr, Lloyd RV: Pituitary carcinoma: A clinicopathological review. Neurosurgery 56:1066-1074; discussion 1066-1074, 2005

69. Strowd R, Salvatori R, Laterra J: Temozolomide retreatment in a recurrent prolactin-secreting pituitary adenoma: Hormonal and radiographic response. J Oncol Pharm Pract 22(3):517522,2016 
70. Syro LV, Uribe H, Penagos LC, Ortiz LD, Fadul CE, Horvath E, Kovacs K: Antitumour effects of temozolomide in a man with a large, invasive prolactin-producing pituitary neoplasm. Clin Endocrinol 65:552-553, 2006

71. Takeshita A, Inoshita N, Taguchi M, Okuda C, Fukuhara N, Oyama K, Ohashi K, Sano T, Takeuchi Y, Yamada S: High incidence of low $\mathrm{O}(6)$-methylguanine DNA methyltransferase expression in invasive macroadenomas of Cushing's disease. Eur J Endocrinol 161:553-559, 2009

72. Vieira Neto L, Chimelli L, Pereira PJ, Gasparetto EL, Bines J, Wildemberg LE, Gadelha MR: The role of temozolomide in the treatment of a patient with a pure silent pituitary somatotroph carcinoma. Endocr Pract 19:e145-149, 2013

73. Whitelaw BC, Dworakowska D, Thomas NW, Barazi S, Riordan-Eva P, King AP, Hampton T, Landau DB, Lipscomb D, Buchanan CR, Gilbert JA, Aylwin SJ: Temozolomide in the management of dopamine agonist-resistant prolactinomas. Clin Endocrinol 76:877-886, 2012

74. Wick A, Pascher C, Wick W, Jauch T, Weller M, Bogdahn $U$, Hau P: Rechallenge with temozolomide in patients with recurrent gliomas. J Neurol 256:734-741, 2009

75. Zacharia BE, Gulati AP, Bruce JN, Carminucci AS, Wardlaw SL, Siegelin M, Remotti H, Lignelli A, Fine RL: High response rates and prolonged survival in patients with corticotroph pituitary tumors and refractory Cushing disease from capecitabine and temozolomide (CAPTEM): A case series. Neurosurgery 74:E447-455; discussion E455, 2014
76. Zada G, Woodmansee WW, Ramkissoon S, Amadio J, Nose V, Laws ER Jr: Atypical pituitary adenomas: Incidence, clinical characteristics, and implications. J Neurosurg 114:336-344, 2011

77. Zemmoura I, Wierinckx A, Vasiljevic A, Jan M, Trouillas J, Francois $\mathrm{P}$ : Aggressive and malignant prolactin pituitary tumors: Pathological diagnosis and patient management. Pituitary 16:515-522, 2013

78. Zhao Y, Xiao Z, Chen W, Yang J, Li T, Fan B: Disulfiram sensitizes pituitary adenoma cells to temozolomide by regulating O6methylguanine-DNA methyltransferase expression. Mol Med Rep 12:2313-2322, 2015

79. Zhu Y SH, Hakimian B, Bonert V, Lim S, Heaney AP: Temodar: Novel treatment for pituitary adenoma (abstract). US Endocr Soc 138:43-45, 2004

80. Zuhur SS, Tanik C, Karaman O, Velet S, Cil E, Ozturk FY, Ozkayalar H, Musluman AM, Altuntas Y: MGMT immunoexpression in growth hormone-secreting pituitary adenomas and its correlation with $\mathrm{Ki}-67$ labeling index and cytokeratin distribution pattern. Endocrine 40:222-227, 2011 